Kleiber, M. \& Luick, J. R. (1956). Ann. N.Y. Acad. Sci. 64, 299.

Kronfeld, D. S. (1965). Vet. Rec. 77, 30.

Kronfeld, D. S., Raggi, F. \& Ramberg, C. F. (1966). I. Dairy Sci. 49, 733.

Lascelles, A. K., Cowie, A. T., Hartmann, P. E. \& Edwards, M. J. (1964). Res. vet. Sci. 5, I90.

Lascelles, A. K., Hardwick, D. C., Linzell, J. L. \& Mepham, 'T. B. (I964). Biochem. J. 92, 36.

Lintzel, W. (1934). Lait 14, I 125 .

Linzell, J. L. (1960a). F. Physiol., Lond. ז53, 492.

Linzell, J. L. (1960)), F. Physiol, Lond. 153, 5 10.

Linzcll, J. L. (1963). Q. Fl exp. Physiol. 48, 34 .

Linzell, J. L. (1966). Circulation Res. 18, 745.

Linzell, J. L. (1967a). F. Physiol., Lond. x9o, 333

Linzell, J. L. (1967h). F. Physiol., Jond. 190, 347.

Linzell, J. L., Annison, E. F., Fazakerley, S. \& Leng, R. A. (1967). Biochem. f. 104, 34.

Linzell, J. L., Mepham, T. B., Annison, E. F. \& West, C. E. (r967). Biochem. \%. ro3, 42P.

Mepham, T. B. \& Linzell, J. L. (1966). Biochem. J. ror, 76.

Mepham, T. B. \& Linzell, J. L. (1967). Nature, Lond. 214, 507.

Peeters, G., Cocquyt, G. \& de Moor, A. (1963). Annls Endocr. 24, 717.

Petersen, W. E. \& Boyd, W. L. (1937). Proc. Soc. exp. Biol. Med. 37, 537.

Popják, G., French, T. H. \& Folley, S. J. (195r). Biochem. F. 48, 4 I I.

Popják, G., French, T. H., Hunter, G. D. \& Martin, A. J. P. (195I). Biochem. F. 48, 612.

Popják, G., Glascock, R. F. \& Folley, S. J. (1952). Biochem. F. 52, 472.

Rasmussen, F. (1963). Acta vet. scand. 4, 271 .

Rasmussen, F. (1965). Acta vet. scand. 6, 135 .

Reynolds, M. (1962). J. Dairy Sci. 45, 742.

Reynolds, M. (1965). Am. F. Physiol. 209, 669.

Sopeña, I. (1944). Revta Fac. Agron. Vet. Univ. B. Aires 11, 308.

Verbeke, R. \& Peeters, G. (1965). Biochem. F. 94, 183 .

West, C. E., Annison, E. F. \& Linzell, J. L. (1967a). Biochem. F. 102, ${ }_{3}$ P.

West, C. E., Annison, E. F. \& Linzell, J. L. (1967b). Biochem. \%. ro4, 59 P.

Wood, H. G., Siu, P. \& Schambye, P. (1957). Archs Biochem. Biophys. 69, 390.

\title{
The biochemistry of the mammary gland
}

\section{By J. M. BARRY, Department of Agriculture, University of Oxford}

As a biochemist I find it useful to think of the mammary gland as a mass of tissue with three principal routes of communication with the outside world: the arterial and venous blood vessels, the afferent and efferent nerves, and the teat orifice. The gland is nourished by components of the arterial blood. Its growth, development and involution are induced by changes in blood composition and rate of flow, by nervous impulses, and by the removal of milk through the teat orifice. Of these routes of communication the blood stream is the most important. Although nervous impulses play a part as, for example, in stimulating the secretion of hormones, nervous connexions to the gland can be severed without disastrous results (Tverskoi, 1957; Linzell, 1960). Also, although the removal of milk through the teat orifice is a factor in stopping and starting milk secretion it is not normally involved in the development of the gland.

Many organic and inorganic compounds, including hormones and metabolic substrates, must be present in the arterial blood for the proper functioning of the gland in all stages of its development. But in this discussion I shall consider only one point: what signals (i.e. changes in blood composition, nervous impulses, etc.) reaching and leaving the mammary gland along the three routes of communication induce its development to full lactation, and then its regression to dryness? This 
is a complex and unresolved topic and there are marked differences between species. I can only attempt a rough and tentative summary of the situation in a mythical beast: the 'average mammal'.

In the newborn female there is little mammary tissue, and the parenchyma consists of a few branching ducts. Before puberty the gland starts to grow more rapidly than the body as a whole, but the increase in size is partly due to increases in adipose and connective tissue. The parenchyma develops consistently only during pregnancy. In the first half or two-thirds of pregnancy the duct system, which will eventually carry milk to the teats, grows and ramifies through the connective and adipose tissue, and clusters of secretory alveoli develop at the ends of the ducts. During the remainder of pregnancy there is usually less growth, but the alveoli become distended with milk (i.e. colostrum). From late pregnancy onwards many mammals will continuously yield milk if it is regularly withdrawn from the gland, although the yield falls during subsequent pregnancies. If milking is stopped outside pregancy the gland involutes.

Mammary growth in pregnancy is inhibited by ovariectomy and restored by administration of oestrogens and progesterone. The concentrations of oestrogens and progesterone in blood have recently been shown to be elevated throughout pregnancy in cows (Short, I958; Pope, Jones \& Waynforth 1965 ), and Heap \& Linzell ( 1966$)$ have shown that the mammary uptake of progesterone from the blood of goats rises in early pregnancy. At first sight these facts suggest that increased concentrations of oestrogens and progesterone in mammary arterial blood are a factor in inducing mammary growth. This is consistent with reports of Lyons and his colleagues (Lyons, $195^{8}$ ) that an oestrogen and progesterone are required (together with adrenal cortical hormones, growth hormone and prolactin) to induce development of ducts and alveoli in rats from which the ovaries, pituitaries and adrenals have been removed. There is also some evidence that oestrogens and progesterone can have direct physiological effects on mammary tissue as, for example, in organ cultures of virgin mammary gland (Mishkinsky, Dikstein, Ben-David, Azeroual \& Sulman, i 967$)$.

However, mammary growth is also inhibited by removal of the pituitary, and evidence has existed for many years that the high levels of oestrogens and progesterone in blood during pregnancy stimulate pituitary secretion. Recent experiments suggest that the signal in mammary arterial blood which induces mammary growth, and also causes the alveoli to become swollen with secretion may be solely an increased level of pituitary prolactin or placental lactogen. Cowie \& Tindal (r964, 1965) have found that twice-daily attempts at milking ovariectomized virgin goats induced almost normal growth of the mammary glands which, after a few months, yielded $\mathrm{I}-2 \mathrm{1}$. milk a day. Growth was not induced if the pituitary stalk was severed, and this suggests that nervous impulses from the teats stimulated the secretion of pituitary prolactin which acted on the gland to induce its development and secretion of milk. Cowie \& Tindal also produced similar results in similar goats by implanting normally inadequate doses of oestrogens and progesterone in the brain near the pituitary, showing that these hormones do in fact stimulate the pituitary. Mammary 
growth has also been induced by injections of prolactin and growth hormone into rats from which the ovaries, adrenals and pituitaries had been removed ('Talwalker \& Meites, 1961). Whether the concentration of pituitary prolactin in blood does in fact rise during pregnancy will soon no doubt be proved by analysis, since a reliable analytical method has recently been developed for mice (Kwa \& Verhofstad, r 967). However, in women, where pituitary prolactin appears to be replaced by a similar placental lactogen, this lactogen is in fact present in blood only during pregnancy (Forsyth, 1967). Although growth hormone may be needed by the growing mammary gland of many animals it does not appear to be the signal which induces mammary growth since its concentration in blood plasma, at least of rats, does not rise in pregnancy or lactation (Schalch \& Reichlin, 1966). Also, although the concentration of adrenal cortical hormones in blood does increase during pregnancy (Bayliss, Browne, Round \& Steinbeck, 1955) these hormones and thyroid hormones can be excluded as signals since removal of the adrenals or thyroid has no marked effect on mammary growth.

If blood of the mature female does in fact contain all the factors required for mammary growth and secretion except adequate prolactin, how does an increase in its concentration during pregnancy induce these changes? Karlson ( $\mathrm{r}^{6}{ }^{6} 3$ ) and others have suggested that hormones which induce developmental changes do so by specific interactions with the correct genes, stimulating them to synthesize messenger RNA which directs the formation of the proteins necessary for development. Dr R. Mayne (unpublished) in my laboratory has in fact shown that the addition of prolactin to organ cultures of the mammary glands of mid-pregnant $\mathrm{C}_{3} \mathrm{H}$ mice is followed about $6 \mathrm{~h}$ later by increased RNA synthesis. However, we incline to the view that prolactin is not a key which unlocks specific genes, but is merely one of the many factors required for optimum metabolism of the gland. In its presence the mammary parenchyma grows, and when growth is completed sccretion appears, possibly influenced by an increased concentration of prolactin, according to a programme laid down within the tissue.

Around parturition the 'initiation of milk secretion' or 'lactogenesis' is said to occur but these terms are not well defined and suggest a more precise change than in fact occurs. 'Towards the end of pregnancy the mammary alveoli are already distended with milk, and some cows will give good yields by ro days or so before parturition. Nevertheless, the yield of a cow milked pre-partum does always rise after parturition and an unmilked gland becomes even more distended with milk; these manifestations of 'lactogenesis' are generally believed to result from hormonal changes. Various hormonal theories have been developed to explain lactogenesis. One suggests that the secretion of prolactin by the pituitary is inhibited by the high concentrations of progesterone in blood during pregnancy. At parturition the progesterone concentration falls and the pituitary secretes more prolactin, which stimulates milk secretion. The progesterone concentration in the blood of cows does in fact fall about Io days before parturition (Short, 1958), when the yields of cows milked before parturition begin to rise (Rowland, Roy, Sears \& Thompson, 1953). However, G. S. Pope (1967, personal communication) has found no precise correlation between the rise 
in milk yield and the fall in plasma progesterone of cows milked before parturition. Other hormonal theories of lactogenesis include a direct inhibition by oestrogens and progesterone of milk secretion which is removed when the blood concentrations fall at parturition. However, evidence for a direct inhibition of secretion by these hormones as, for example, in organ culture or when they are injected, with prolactin, into a teat duct of a rabbit, has never been reported. It seems possible that the rise in milk yield at parturition is not induced by hormonal changes but by increased amounts of metabolites becoming available to the gland. The rate of blood flow through the gland of a goat rises by two or three times after parturition. It has been suggested that this is simply a consequence of diversion of blood from the uterus (Reynolds, 1965), and hence it could be a cause rather than a consequence of increased milk yield. Moreover, since the foetus no longer needs nourishing after parturition, the concentrations of certain metabolites in blood may rise.

The greatest influence on milk yield at parturition is certainly removal of milk: if only two quarters of a cow are milked, a similar volume does not leak from the other two quarters. There is good evidence that removal of milk stimulates secretion by some mechanism which is not hormonal. Thus, Wheelock, Smith \& Dodd (1967) report experiments in which the milking of two quarters of cows was stopped in midlactation and resumed 2 weeks later. The quarters that were continuously milked showed no reduction in yield. On resumption of milking, the other two quarters gave little milk at first, but gradually recovered to give between $10 \%$ and $70 \%$ of their previous yields. This recovery of milk yield cannot be attributed to hormones released as a result of stimulation of the teats since two teats had been stimulated without interruption.

After a period of secretion there always comes a time when the milk yield of an animal begins to decline, and it declines most rapidly if the animal becomes pregnant. Also, if milking is stopped secretion stops after a few days. It has generally been believed that these reductions in yield are primarily induced by changes in hormone concentrations in mammary arterial blood. The results of various experiments have been taken to suggest that high concentrations of pituitary hormones. and especially of prolactin, must be present in mammary arterial blood to maintain secretion and that a gradual fall in yield can result from a gradual fall in these hormone concentrations. During pregnancy, prolactin secretion and action have been thought to be antagonized by increasing concentrations of oestrogens and progesterone. However, recent evidence suggests that high concentrations of prolactin in blood may not be required during lactation. Cowie \& Tindal $\left({ }^{1} 9^{65}\right)$ have found that severing the pituitary stalk of a lactating goat reduces the goat's milk yield, but that this can be fully restored by administering growth hormone. Also, as already mentioned, placental lactogen is not present in human blood during lactation. Hardwick \& Linzell (i960) have found that prolactin and other hormones in the perfusing fluid do not increase the milk yield of the perfused gland of a goat. Linzell ( 1963$)$ has also removed a lactating gland from a female goat and connected it to the blood supply of a male, and found little reduction of milk yield until after $3^{6 \mathrm{~h}}$. Mr D. P. Leader in my laboratory is studying the increase in glucose-6-phosphate 
dehydrogenase in organ cultures of mammary tissue taken from $\mathrm{C}_{3} \mathrm{H}$ mice just before parturition. In synthetic medium the maximum rise over $48 \mathrm{~h}$ requires insulin and prolactin; but the prolactin can be replaced by $10 \%$ of blood serum from a virgin mouse, suggesting that it is not a specific requirement. 'There is, however, strong evidence that suckling stimulates the secretion of prolactin by the pituitary (Selye, 1934) possibly via the release of oxytocin (Benson \& Folley, 1957). In one experiment Selye showed that suckling at only one set of nipples of a rat delayed involution of the glands where suckling had been prevented, but evidence was not presented that their milk yield was maintained. Hence high concentrations of prolactin do appear to maintain the structure of a gland at which milking has stopped. But an experiment of Smith, Wheelock \& Dodd ( 1966 ), which was basically a repetition on cows of Selye's experiment on rats, suggests that any stimulation of prolactin secretion does not prevent a fall in milk yield. It was found that two quarters of a pregnant cow can be dried off at a normal rate by stopping milking, without the milk yield of the other two quarters being affected. The glands were not examined microscopically as in Selye's experiment. It does therefore, appear possible that factors other than changes in the hormone concentrations of mammary arterial blood may be the cause of reduced milk yields. Some possible factors are gradual loss of secretory cells through ageing; reduction in mammary blood flow and blood metabolite concentrations during pregnancy; inhibition of milk secretion by unremoved milk caused by an unknown mechanism; and disintegration of alveolar cells by the pressure of unremoved milk, which has been shown to occur.

In summary, I suggest the following very tentative conclusions about the signals which induce the mammary gland to change its structure and function. That both growth of the gland and accumulation of secretion in the alveoli are induced by increased concentrations of prolactin in the mammary arterial blood. That the stimulation of secretion normally occurring around parturition is not induced by changes in hormone concentrations in mammary arterial blood, but by the removal of milk from the gland and by increasing supplies of metabolites. That secretion is not normally depressed by changes in hormone concentrations in mammary arterial blood but by gradual loss of secretory cells, decreased supplies of metabolites during pregnancy, and by unremoved milk.

\section{REFERENCES}

Bayliss, R. I. S., Browne, J. C. McC., Round, B. P. \& Steinbeck, A. W. (1955). Lancet i, 62.

Benson, G. K. \& Folley, S. J. (1957). F. Endocrin. 16, I89.

Cowie, A. T. \& 'Tinda1, J. S. (1964). Rep. natn. Inst. Res. Dairy. p.55.

Cowic, A. T. \& Tindal, J. S. (1965). Rep. natn. Inst. Res, Dairy. p.54.

Forsyth, I. (1967). In Hormones in Blood, and ed. Vol. r, p.233. [C. H. Gray, editor.] London: Academic Press Inc.

Hardwick, D. C. \& Linzell, J. L. (1960). F. Physiol., Lond. 154, 547.

Heap, R. B. \& Linzell, J. L. (1966). F. Endocrin. 36, 389.

Karlson, P. (1963). Perspect. Biol. Med. 6, 203.

Kwa, H. G. \& Verhofstad, F. (I 967). Biochim. biophys. Acta 133, 186.

Linzell, J. L. (т960). Nature, Lond. т88, 596.

Linzell, J. L. (1963). Q. Fl exp. Physiol. 48,34. 
Lyons, W. R. (1958). Proc. R. Soc. B r49, 303.

Mishkinsky, J., Dikstein, S., Ben-David, M., Azeroual, J. \& Sulman, F. G. (r967). Proc. Soc. exp. Biol. Med. 125, 360 .

Pope, G. S., Jones, H. E. H. \& Waynforth, H. B. (1965). F. Endocrin. 33, 385.

Reynolds, M. (1965). Fedn Proc. Fedn Am. Socs exp. Biol. 24, 45 I.

Rowland, S. J., Roy, J. H. B., Sears, H. J. \& Thompson, S. Y. (I953). F. Dairy Res. zo, I6.

Schalch, D. S. \& Reichlin, S. (r966). Endocrinology 79, 275.

Selye, I. (r934). Am. F. Physiol. 107, 535 .

Short, R. V. (1958). F. Endocrin. 16, 426.

Smith, A., Wheelock, J. V. Dodd, F. H. (1966). \%. Dairy Sci. 49, 895.

Talwalker, P. K. \& Meites, J. (Ig6r). Proc. Soc. exp. Biol. Med. ro7, 880.

Tverskoi, G. B. (1957). Zh. obschch. Biol. 18, 169.

Wheelock, J. V., Smith, A. \& Dodd, F. H. (1967). F. Dairy Res. 34, I5 I.

\section{The amount and physical form of feed and milk secretion in the cow}

\section{By D. G. Armstrong, University of Newcastle upon Tyne}

Among factors which affect milk secretion in the cow are breed, age, stage of lactation, disease, management and nutrition. This paper is concerned with two aspects of the last-mentioned. In the previous contributions to this Symposium the precursors of milk constituents in the blood and the control mechanisms and metabolic pathways by which they are synthesized into milk constituents have been discussed. In this paper the extent to which present knowledge concerning the end-products of digestion and their subsequent metabolism within the body can account for the known effects of the amount of food and its physical form on milk yield and composition will be examined.

Early intervention of microbial fermentation in the digestive processes of the ruminant complicates the task on at least two counts. Firstly reliable quantitative information on the end-products of digestion in the lactating cow is almost totally lacking. Secondly the end-products of carbohydrate digestion, the volatile fatty acids (VFA), are metabolized within the body by quite different metabolic pathways and, while a considerable amount is known concerning the specific pathways followed by individual acids, much less is known concerning the metabolic interrelationships of the acids within the body. A third complication, not necessarily restricted to the ruminant, is the capacity of the lactating animal to draw upon supplies of body energy to maintain milk secretion during early lactation.

Among the more recent of several excellent reviews on the subject of nutrition and milk secretion are those by Rook ( $196 \mathrm{r} a, b$ ), Van Soest ( 1963 ), Huber $\&$ Boman (1966b) and Kirchgessner, Friesecke \& Koch (1 967 ). Only brief reference will therefore be made to the effects on milk yield and composition, of the amount of food fed and its physical form. It is necessary to note that some nutritional factors induce equal changes in yicld of milk and its principal components, namely fat and solidsnot-fat (SNF) comprising essentially lactose and protein; such factors therefore affect milk yield but not milk composition. Some factors induce changes in certain 